\title{
PENGARUH RASIO MBTS/ZDEC PADA CAMPURAN KARET ALAM DAN ETILEN PROPILEN DIENA YANG DIBUAT DENGAN TEKNIK KONTROL MIGRASI CURATIVES
}

\section{THE EFFECT OF MBTS/ZDEC RATIO ON NATURAL RUBBER AND ETHYLENE PROPYLENE DIENE RUBBER BLENDS PREPARED BY CURATIVES MIGRATION CONTROL TECHNIQUE}

\author{
Ihda Novia Indrajati*, Muhammad Sholeh \\ Balai Besar Kulit, Karet, dan Plastik Yogyakarta \\ *E-mail: i-novia@kemenperin.go.id
}

Diterima: 27 Februari 2014 Direvisi: 20 Mei 2014 Disetujui: 23 Mei 2014

\begin{abstract}
The objective of this research was to observe the effect of MBTS/ZDEC ratio on dynamic properties, curing characteristic, morphology as well as hardness and resiliency of the NR/EPDM blends prepared by curatives migration control technique. The MBTS/ZDEC ratio were 1.6/0.0; $1.5 / 0.1 ; 1.4 / 0.2 ; 1.3 / 0.3$ and $1.2 / 0.4$ respectively on a fixed NR/EPDM ratio of 60/40. Compounds (EPDM and NR) were prepared separately using two roll mill. The blends with binary accelerator MBTS/ZDEC showed synergistic activity which provided higher crosslink density than those of single accelerator MBTS. Reduction of $t_{2}$ and $t_{90}$ as well as cure rate index (CRI) indicated the more homogeneous crosslink density distribution within the rubber phase. Scanning electron micrograph showed that the blends with binary accelerator gave smoother surface. Binary accelerator resulted higher hardness. Increasing of ZDEC raised hardness followed by reduction of the resillience property.
\end{abstract}

Keywords: NR/EPDM blends, MBTS, ZDEC, cure characteristic

\begin{abstract}
ABSTRAK
Penelitian ini bertujuan mempelajari pengaruh rasio MBTS/ZDEC pada sifat dinamik, karakteristik curing, karakteristik morfologi serta kekerasan dan sifat pegas pantul campuran NR/ EPDM yang dibuat dengan teknik kontrol migrasi curatives. Rasio MBTS/ZDEC yang digunakan dalam penelitian ini secara berurutan $1,6 / 0,0 ; 1,5 / 0,1 ; 1,4 / 0,2 ; 1,3 / 0,3 ;$ dan $1,2 / 0,4$ pada rasio NR/ EPDM tetap 60/40. Kompon dibuat secara terpisah (kompon EPDM dan NR) menggunakan two roll mill. Campuran NR/EPDM dengan akselerator biner MBTS/ZDEC menunjukkan sinergi aktivitas yang memberikan kerapatan ikatan silang lebih tinggi daripada akselerator tunggal MBTS. Kemampuan proses kompon akselerator biner lebih rendah daripada akselerator tunggal. Penurunan $\mathrm{ts}_{2}$ dan $\mathrm{t}_{90}$ serta kenaikan indeks kecepatan reaksi (CRI) mengindikasikan distribusi ikatan silang yang merata pada kedua fasa karet. Mikrograf pemindaian elektron (SEM) menunjukkan campuran dengan akselerator biner mempunyai permukaan yang lebih halus. Kekerasan vulkanisat sistem biner lebih tinggi. Penambahan ZDEC meningkatkan kekerasan dan diikuti dengan penurunan sifat pegas pantul.
\end{abstract}

Kata kunci: campuran NR/EPDM, MBTS, ZDEC, karakteristik cure 


\section{PENDAHULUAN}

Karet alam (NR) merupakan polimer biosintesis alami yang mempunyai elemen-elemen dengan kisaran yang atraktif, dengan sifat mekanik dan dinamik yang baik serta mempunyai karakteristik proses yang baik (Arayapranee and Rempel, 2007; Sahakaro et al., 2009). Rantai utama (backbone) NR bersifat sangat tidak jenuh sehingga rawan terdeteriorasi akibat serangan ozon (Nabil et al., 2013a). Upaya meningkatkan ketahanan ozon NR dapat ditempuh dengan mencampurnya dengan karet etilen propilen diena (EPDM). Fasa EPDM yang terdispersi secara merata dalam karet tidak jenuh merupakan antioksidan internal yang efektif dibanding antioksidan konvensional seperti $N$-(1,3-dimethylbutyl)-N'-phenylp-phenylene-diamine (6PPD (Sahakaro et al., 2009).

Pencampuran dua atau lebih tipe karet merupakan upaya menyiapkan bahan dengan sifat-sifat yang tidak ditemui pada masingmasing komponen individu. Dalam campuran NR/EPDM sifat fisis yang tinggi sulit dicapai sebagai akibat adanya ketidaksesuaian kematangan (cure incompatibility) antara NR dan EPDM.Perbedaantingkatkejenuhan(saturation) kedua jenis karet tersebut menyebabkan ketidaksesuaian kematangan terutama pada sistem vulkanisasi sulfur (Sahakaro et al., 2009; Nabil et al., 2013). Solubilitas curative yang rendah dalam fase EPDM dibanding dalam fase NR juga merupakan faktor yang dapat mengurangi terbentuknya ikatan silang pada fase EPDM (Sae-oui et al., 2007). Curative secara alamiah akan lebih banyak terdapat pada fasa karet tidak jenuh saat vulkanisasi. Oleh karena itu, diperlukan kontrol migrasi curative agar diperoleh distribusi yang homogen pada kedua fase karet. Sahakaro et al. (2009) dan Nabil et al. (2013) melakukan pengontrolan migrasi curative dengan membentuk ikatan silang parsial pada fase EPDM. Ikatan silang parsial merupakan fragmen akselerator yang menempel pada rantai EPDM. Oleh karena itu migrasi menuju fase NR yang tidak jenuh akan terhambat dan menghasilkan distribusi curative lebih homogen pada kedua fasa karet.

Akselerator memegang peranan penting pada vulkanisasi karet. Disamping mempercepat proses, akselerator juga mempengaruhi sifat fisis dan kimia vulkanisat (Alam et al, 2012). Pada campuran NR/EPDM, akselerator polar akan tertahan pada fasa NR yang tidak jenuh sehingga konsetrasinya tidak merata pada kedua fasa. Akibatnya pada fasa NR mengandung ikatan silang lebih banyak (Sahakaro et al., 2009). Penggunaan akselerator dengan solubilitas yang besar dalam fasa EPDM dapat meningkatkan kompatibilitas curing campuran. Akselerator dengan substitusi rantai alkil panjang dapat meningkatkan sifat-sifat campuran yang mengandung EPDM (Sae-oui et al., 2007). EPDM memerlukan akselerator ultracepat karena karakteristik curing instrinsiknya rendah (Dijkhuis et al., 2009). Penelitian menggunakan berbagai jenis akselerator tunggal pada campuran NR/EPDM telah dilakukan, diantaranya yaitu MBT (Sae-oui et al., 2007; Sahakaro et al., 2009; Nabil et al., 2013), MBTS (Sae-oui et al., 2007; Sahakaro et al., 2009), TBBS (Sae-oui et al., 2007; Sahakaro et al., 2009; Nabil et al., 2013), CBS (Sahakaro et al., 2009; Nabil et al., 2013) dan TMTD (Sae-oui et al., 2007; Nabil et al., 2013).

Penggunaan dua atau lebih akselerator secara simultan lebih menguntungkan untuk aplikasi teknologi karena sistem kombinasi akselerator menunjukkan aktivitas vulkanisasi yang lebih tinggi (sinergisme) daripada akselerator tunggal secara terpisah.Interaksi antara akselerator pada sistem biner menghasilkan senyawa reaktif yang akan terdekomposisi menjadi radikal bebas atau ion-ion. Senyawa tersebut dapat menginisiasi reaksi antara sulfur dengan karet dan pada akhirnya proses pembentukan ikatan silang (Alam et al., 2012).

Zinc dithiocarbamate (ZDC) digunakan secara luas dalam teknologi vulkanisasi terutama pada barang lateks. ZDC tidak menimbulkan rasa dan bau pada vulkanisat serta menunjukkan karakteristik pengusangan yang baik. ZDC merupakan booster jika dikombinasikan dengan $N$-cyclohexyl-2-benzothiazole sulfenamide (CBS), 2-mercaptobenzothiazole (MBT) dan dibenzothiazyldisulfie (MBTS). Sistem akselerator biner tersebut digunakan pada vulkanisasi karet diena dan karet butil yang berkarakteristik curing lambat (Alam et al., 2012). Akselerator jenis ini disamping mempercepat reaksi vulkanisasi te- 
tapi juga dapat berfungsi sebagai anti degradasi (Alam et al., 2014). Bhowmick and Mangaraj (1994) menyatakan bahwa kombinasi MBTS dengan ZDC memberikan keseimbangan yang baik pada kecepatan reaksi vulkanisasi dan pembentukan ikatan silang pada karet EPDM. Debnath dan Basu (1994) melakukan penelitian menggunakan kombinasi zincdibenzyldithiocarbamate (ZBEC) dengan MBTS pada NR, dan Alam et al. (2012) menggunakan kombinasi zinc dimethyldithiocarbamate (ZDMC) dengan MBTS pada NR. Kedua penelitian tersebut menunjukkan pembentukan thiuram disulfid (TMTD) dan merkaptobenzotiazol (MBT) sebagai hasil reaksi antara ZDC dengan MBTS. TMTD dan MBT merupakan akselerator yang sangat aktif. Informasi terkait penggunaan kombinasi akselerator ZDC/MBTS pada NR dan belum ditemukan untuk campuran NR dengan EPDM.

Tujuan penelitian ini adalah mempelajari pengaruh rasio akselerator MBTS/ZDEC terhadap sifat dinamik, karakteristik curing, karakteristik morfologi, kekerasan dan ketahanan pegas pantul campuran NR/EPDM yang dibuat menggunakan pencampuran reaktif teknik kontrol migrasi curative. Modifikasi terhadap metode yang dikembangkan oleh Sahakaro et al. (2009) dan Nabil et al. (2013) adalah dengan menambahkan carbon black dan compatibilizer maleat anhidrid (MAH) pada kompon NR. Hal tersebut dilakukan untuk meningkatkan kompatibilitas NR dengan EPDM.

\section{BAHAN DAN METODE}

\section{Bahan Penelitian}

Bahan penelitian terdiri dari karet alam jenis pale crepe yang diperoleh di pasaran, Karet EPDM jenis Keltan 4551 A, High Abrasion
Furnace (HAF) Black Ex. OCI, General Purpose Furnace (GPF) Black Ex. Korea, castor oil (Bratachem), polimer 2,2,4-trimethyl-1,2-dihydroquinoline (TMQ) Ex. Kemai, paraffin wax Antilux 654A, ZnO (Bratachem), Aflux 42M, 2,2'-Dithiobis(benzothiazole) (MBTS) Ex. Shandong Sianxian, zinc diethyl dithiocarbamate (ZDEC), Sulfur SP-325 Ex. Miwon, maleat anhidrid (MAH) dan dicumyl peroxide (DCP).

\section{Peralatan Penelitian}

Peralatan yang digunakan dalam penelitian ini meliputi two roll mill skala laboratorium, mesin kempa hidrolik, moving die rheometer (MDR) Gotech 3000A, mikroskop pemindai elektron (SEM) merek JEOL dengan perbesaran 1000x.

\section{Metode Penelitian \\ Pembuatan kompon}

Kompon dibuat dalam dua bagian, yaitu kompon EPDM(E) dan kompon NR. Kedua kompon tersebut diproses menggunakan two roll mill. Komposisi kompon EPDM dan NR disajikan pada Tabel 1 dan Tabel 2. Pada kompon EPDM (E1-E5) dilakukan pemanasan awal menggunakan mesin kempa hidrolik sebelum dicampur dengan kompon NR. Waktu pemanasan awal (Tabel 3) ditetapkan $75 \%$ dari $\mathrm{ts}_{2}$ hasil pengujian dengan MDR pada suhu $170^{\circ} \mathrm{C}$. Selanjutnya masing-masing kompon EPDM dicampur dengan kompon NR. Kompon NR/EPDM disimpan dalam ruang kondisi selama 24 jam sebelum divulkanisasi.

\section{Pengukuran sifat dinamik dan karaketeristik curing}

Karakteristik curing campuran NR/EPDM diuji menggunakan MDR pada suhu $160^{\circ} \mathrm{C}$.

Tabel 1. Komposisi bahan kompon EPDM

\begin{tabular}{cccccccccccc}
\hline \multirow{2}{*}{ Kode } & \multicolumn{10}{c}{ Konsentrasi (phr) } \\
\cline { 2 - 12 } & EPDM & ZnO & Aflux & HAF & GPF & TMQ & Wax & CO $^{*}$ & MBTS & ZDEC & Sulfur \\
\hline E1 & 40,0 & 5,0 & 1,0 & 30,0 & 40,0 & 1,0 & 0,5 & 5,0 & 1,6 & 0,0 & 1,0 \\
E2 & 40,0 & 5,0 & 1,0 & 30,0 & 40,0 & 1,0 & 0,5 & 5,0 & 1,5 & 0,1 & 1,0 \\
E3 & 40,0 & 5,0 & 1,0 & 30,0 & 40,0 & 1,0 & 0,5 & 5,0 & 1,4 & 0,2 & 1,0 \\
E4 & 40,0 & 5,0 & 1,0 & 30,0 & 40,0 & 1,0 & 0,5 & 5,0 & 1,3 & 0,3 & 1,0 \\
E5 & 40,0 & 5,0 & 1,0 & 30,0 & 40,0 & 1,0 & 0,5 & 5,0 & 1,2 & 0,4 & 1,0 \\
\hline
\end{tabular}

*) CO: castor oil 
Tabel 2. Komposisi bahan kompon NR

\begin{tabular}{cc}
\hline Bahan & Konsentrasi (phr) \\
\hline Pale crepe & 60,0 \\
HAF & 10,0 \\
GPF & 10,0 \\
MAH & 3,0 \\
DCP & 0,9 \\
\hline
\end{tabular}

Tabel 3. Waktu pemanasan awal kompon EPDM

\begin{tabular}{cccccc}
\hline Waktu (sekon) & E1 & E2 & E3 & E4 & E5 \\
\hline $\mathrm{ts}_{2}$ & 967 & 68 & 68 & 43 & 36 \\
$\mathrm{t}_{\mathrm{pa}}{ }^{*}$ & 644 & 45 & 30 & 30 & 24 \\
\hline
\end{tabular}

$*$ pa $=$ pemanasan awal

Keluaran data MDR meliputi torsi elastisitas maksimum ( $\mathrm{S}^{\prime} \mathrm{MH}$ ) dan minimum ( $\mathrm{S}^{\prime} \mathrm{ML}$ ), torsi viskos pada elastisitas maksimum (S"MH), waktu scorch $\left(\mathrm{ts}_{2}\right)$ dan waktu optimum vulkanisasi $\left(\mathrm{t}_{90}\right)$. Faktor damping $(\tan \delta)$ diperoleh dengan membagi S" dengan S'. Cure rate index (CRI) merupakan pengukuran indeks kecepatan reaksi berdasarkan perbedaan $\mathrm{t}_{90}$ dan ts ${ }_{2}$ yang dihitung dengan persamaan (1) berikut (Nabil et al., 2013a).

$$
\mathrm{CRI}=\frac{100}{\left(\mathrm{t}_{90}-\mathrm{t}_{\mathrm{s} 2}\right)}
$$

\section{Pembuatan contoh uji dan pengujian}

Kompon yang telah dikondisi divulkanisasi menggunakan mesin kempa hidrolik pada suhu $160^{\circ} \mathrm{C}$ dan tekanan $150 \mathrm{~kg} / \mathrm{cm}^{2}$. Pengujian kekerasan menggunakan metode uji sesuai dengan SNI 0778:2008 menggunakan manual Shore A durometer, sedangkan sifat pegas pantul menggunakan Wallace Dunlop Tripsometer.

\section{Karakterisasi morfologi campuran}

Morfologi campuran NR/EPDM diamati dengan alat Scanning Electron Microscopy (SEM) pada perbesaran 1000x. Pengamatan dilakukan pada penampang lintang vulkanisat NR/EPDM.

\section{HASIL DAN PEMBAHASAN Sifat Dinamik}

Sifat mengalir (flow properties) penting dipelajari untuk memperoleh produk akhir yang baik. Karet bersifat viskoelastis baik dalam bentuk kompon maupun vulkanisat, sehingga sifat mengalirnya dipengaruhi oleh elemen elastis dan viskos (viscous). Pengaruh rasio MBTS/ZDEC terhadap sifat dinamik disajikan pada Tabel 4.

Torsi elastisitas minimum (S'ML) merupakan indikator viskositas kompon (Konar and Saha, 2012; Marković, 2013; Indra et al., 2013) serta memberikan informasi terkait kemampuan proses dari kompon (Nabil et al., 2013a).Viskositas kompon meningkat dari R1 hingga R5 ditunjukkan oleh kenaikan S'ML (Tabel 3). Penambahan ZDEC 0,1 phr (R2) meningkatkan S'ML hingga 54\%. Penambahan ZDEClebihlanjuttidakmemberikan peningkatan S'ML yang signifikan (maksimum 2\%). Torsi viskos minimum (S"ML) menunjukkan peningkatan dari R1 hingga R5. Penambahan ZDEC 0,1 phr (R1) meningkatkan S"ML hingga $8,6 \%$ dibanding dengan R5. Penambahan ZDEC lebih lanjut tidak signifikan menaikkan S"ML (maksimum 4,9\%).

Viskositas kompon dengan sistem akselerator biner MBTS/ZDEC (R2-R5) lebih tinggi daripada kompon dengan akselerator tunggal MBTS (R1). Hal tersebut disebabkan pada kompon R2-R5 elemen elastis mendominasi (S'ML>S'ML). Namun pada kompon R1 jus-

Tabel 4. Elemen dinamik vulkanisat campuran NR/EPDM

\begin{tabular}{|c|c|c|c|c|c|c|c|}
\hline $\begin{array}{l}\text { Kode } \\
\text { (rasio) }\end{array}$ & $\begin{array}{c}\mathrm{S}^{\prime} \mathrm{MH} \\
\text { (kg.cm) }\end{array}$ & $\begin{array}{c}\text { S'ML } \\
\text { (kg.cm) }\end{array}$ & $\begin{array}{c}\mathrm{S}^{\prime}(\mathrm{MH}-\mathrm{ML}) \\
(\mathrm{kg} \cdot \mathrm{cm})\end{array}$ & $\begin{array}{l}\text { S" (ML) } \\
\text { (kg.cm) }\end{array}$ & $\begin{array}{l}\text { S" (MH) } \\
\text { (kg.cm) }\end{array}$ & $\begin{array}{l}\operatorname{Tan} \delta \\
\text { (ML) }\end{array}$ & $\operatorname{Tan} \delta(\mathrm{MH})$ \\
\hline R1 $(1,6 / 0,0)$ & 24,99 & 3,26 & 21,73 & 4,03 & 7,00 & 1,236 & 0,280 \\
\hline R2 $(1,5 / 0,1)$ & 35,10 & 5,02 & 30,08 & 4,41 & 4,29 & 0,878 & 0,122 \\
\hline R3 $(1,4 / 0,2)$ & 39,46 & 5,12 & 34,34 & 4,29 & 4,01 & 0,838 & 0,102 \\
\hline R4 $(1,3 / 0,3)$ & 43,06 & 5,28 & 37,78 & 4,50 & 3,60 & 0,852 & 0,084 \\
\hline R5 $(1,2 / 0,4)$ & 48,01 & 5,38 & 42,63 & 4,59 & 3,37 & 0,853 & 0,070 \\
\hline
\end{tabular}

S': torsi elastis (E); S": torsi viskos (V); Tan $\delta$ : rasio V/E 
tru sebaliknya, elemen viskos mendominasi ditunjukkan dengan S'(ML) lebih rendah daripada S"(ML). Dominasi elemen elastis pada sistem biner MBTS/ZDEC berkaitan dengan pencampuran reaktif NR/EPDM, dimana pada fase EPDM telah terbentuk ikatan silang parsial sebelum dicampur dengan kompon NR (Nabil et al., 2013). Pembentukan ikatan silang diawali dengan terbentuknya zat aktif sulfurating (active sulfurating agent). Kompleks akseleratorpolisulfidik merupakan zat aktif sulfurating yang baik dibanding dengan sulfur molekuler. Kompleks tersebut terbentuk sebagai hasil interaksi antara molekul akselerator dengan sulfur molekuler (Ghosh et al., 2003). Sistem akselerator biner MBTS/ZDEC memberikan aktivitas sinergi, dimana interaksi antara keduanya menghasilkan MBT dan TMTD secara simultan (Alam et al., 2012).

Pembentukan MBT dan TMTD (Gambar 1) telah dibuktikan oleh Alam et al. (2012) melalui kromatogram HPLC. MBTS terdekomposisi menjadi MBT dengan adanya pemanasan, selanjutnya MBT yang terbentuk bereaksi dengan
ZDEC melepaskan TMTD. MBT yang terbentuk secara insitu mempunyai reaktivitas lebih tinggi daripada yang ditambahkan dari luar sistem (Alam et al., 2014). TMTD akan bereaksi dengan sulfur dan dipercepat dengan $\mathrm{ZnO}$ sebagai katalis. Reaksi tersebut menghasilkan thiuram polysulfides (TMTP) yang merupakan zat aktif sulfurating dengan reaksi disajikan pada Gambar 2.

Jika MBTS sebagai akselerator tunggal (R1), maka hanya akan terbentuk MBT sebagai hasil dekomposisinya. Seperti halnya TMTD, MBT akan bereaksi dengan sulfur dibantu oleh ZnO menghasilkan MBT-polisulfidik (MBTP) yang merupakan zat aktif sulfurating (Gambar 3). Reaksi MBT dengan ZnO tidak dapat berlangsung sempurna karena pada permukaan $\mathrm{ZnO}$ terbentuk lapisan Zn-MBT (ZMBT) yang bersifat tidak larut (insoluble). ZMBT akan menghambat reaksi $\mathrm{ZnO}$ dengan MBT selanjutnya (Ghosh et al., 2003). Oleh karenanya pembentukan zat aktif sulfurating pun akan berkurang.

Zat aktif sulfurating (TMTP maupun

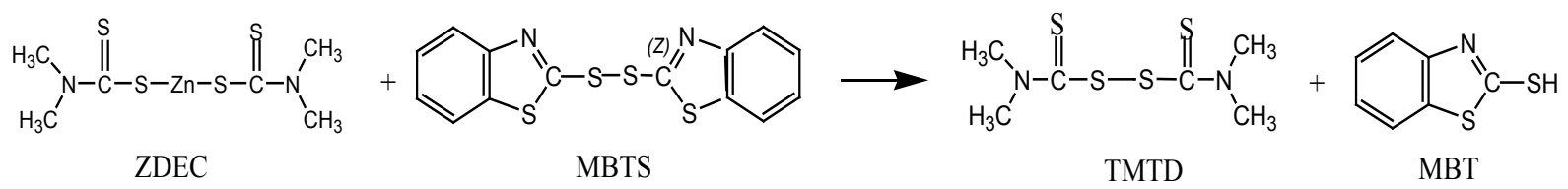

Gambar 1. Reaksi ZDEC dengan MBTS menghasilkan MBT dan TMTD

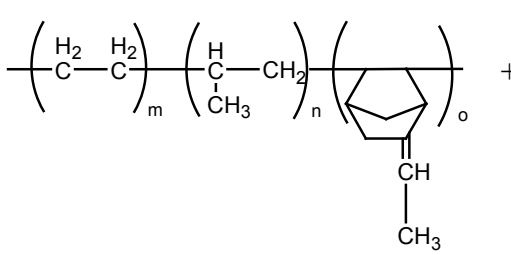

EPDM

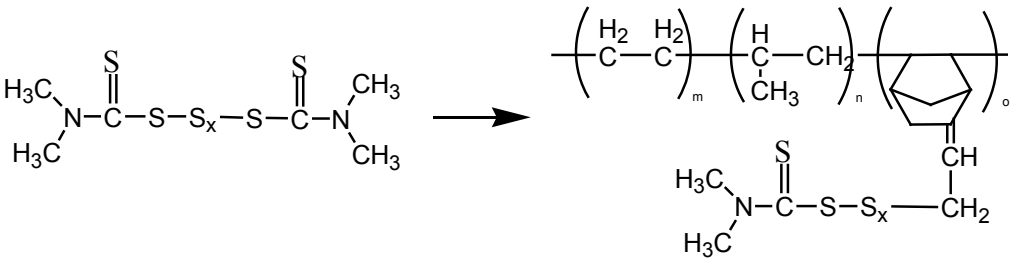

TMTP

Gambar 2. Reaksi TMTP sebagai zat aktif sulfurating dengan EPDM

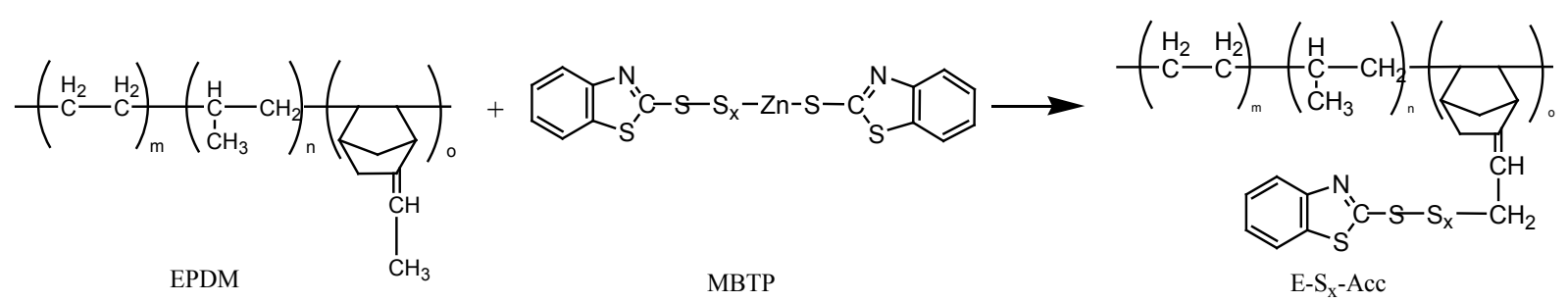

Gambar 3. Reaksi MBTP sebagai zat aktif sulfurating dengan EPDM 
MBTP) kemudian bereaksi dengan rantai EPDM membentuk gugus pendant EPDMakselerator polisulfidik (E-S -Acc) seperti reaksi pada Gambar 2 dan 3. Gugus pendant E-S -Acc yang kemudian disebut sebagai ikatan silang parsial. Gugus tersebut bertindak sebagai precursor ikatan silang pada reaksi vulkanisasi. Pembentukan ikatan silang parsial menghambat migrasi curative dari fasa EPDM menuju NR pada saat vulkanisasi, sehingga distribusi ikatan silangnya lebih merata di kedua fasa karet. Ikatan silang parsial menghambat pergerakan rantai molekul EPDM karena elemen elastis mulai mendominasi, sehingga sifat mengalirnya pun menurun. Viskositas kompon meningkat dan memberikan efek negatif pada kemampuan proses kompon (Nabil et al., 2013a). Untuk dapat menghasilkan produk dengan bentuk yang sempurna dibutuhkan sifat aliran (flow properties) yang baik untuk memenuhi seluruh rongga (cavity) cetakan hingga dicapai waktu scorch $\left(\mathrm{ts}_{2}\right)$. Viskositas kompon yang besar

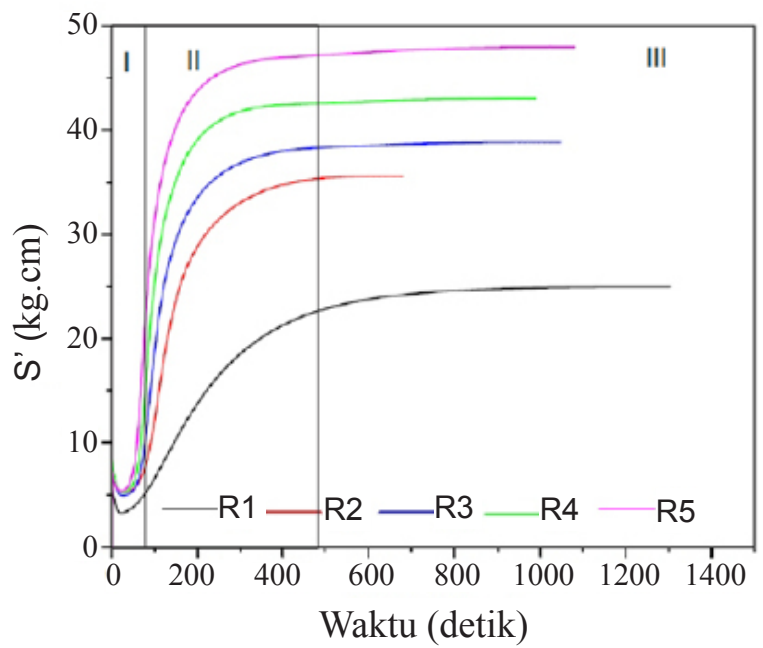

menurunkan sifat mengalirnya sehingga sulit untuk memenuhi rongga-rongga dalam cetakan. Akibatnya produk menjadi tidak sempurna.Oleh karena itu, kenaikan viskositas kompon dari R1 hingga R5 akan memperbesar efek negatif pada kemampuan proses kompon.

Kurva Rheometer (Gambar 4(a)) terbagi menjadi tiga daerah, yaitu induksi (I), curing (II) dan fase pasca curing. Fase awal merupakan fase keselamatan proses (daerah I), dimana elemen viskos (plastis) kompon mendominasi. Ketika dicapai tahap pravulkanisasi $\left(\mathrm{ts}_{2}\right)$ (Gambar 4(b)) maka sifat mengalir kompon menurun dan elemen elastis mulai mendominasi ditandai dengan mulai terbentuknya ikatan silang. Ikatan silang final dibentuk dari interaksi precusor ikatan silang (E-S-Acc) dengan molekul NR seperti pada reaksi pada Gambar 5.

Torsi elastisitas maksimum ( $\left.\mathrm{S}^{\prime} \mathrm{MH}\right)$ merepresentasikan ikatan silang maksimum yang terbentuk selama vulkanisasi. Tabel 4 menunjukkan S'MH meningkat dari R1 hingga R5

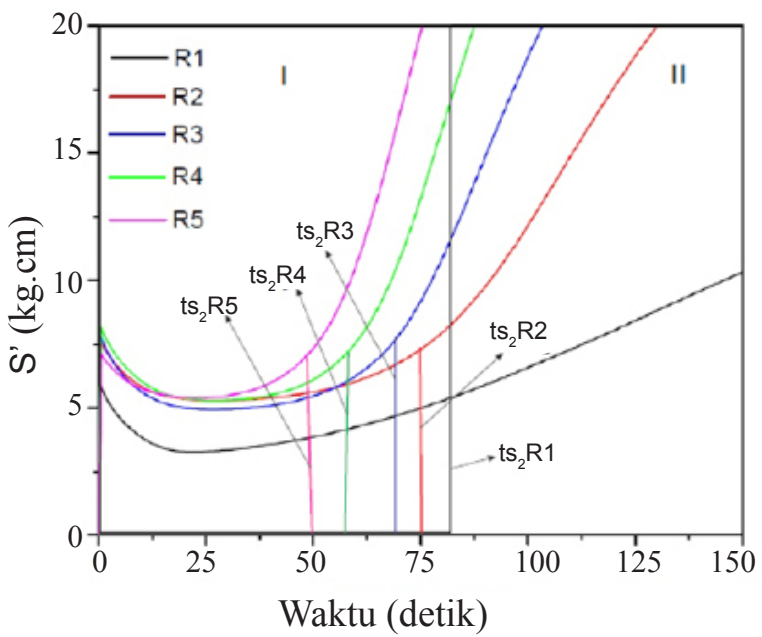

Gambar 4. (a) Plot torsi vs waktu pada suhu $160^{\circ} \mathrm{C}$, (b) inzet dari 0-150 detik

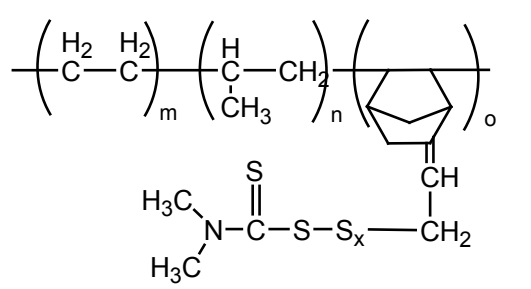

EPDM-S - Acc<smiles>CC(=CC(C)(C)C)CC(C)(C)C</smiles>

NR

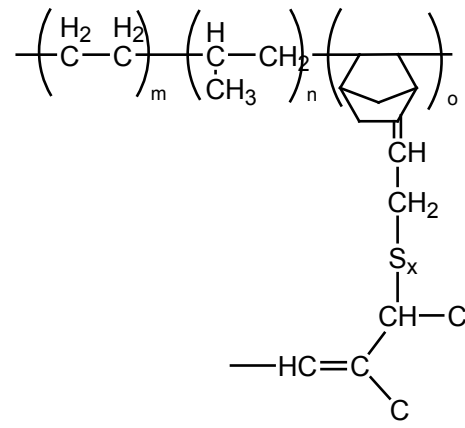

NR/EPDM

Gambar 5. Interaksi precusor ikatan silang (E-S - Acc) dengan molekul NR 
dan sistem biner MBTS/ZDEC memberikan S"MH lebih tinggi daripada akselerator tunggal MBTS. Penambahan ZDEC 0,1 phr (R2) meningkatkan S"MH hingga 40,5\% terhadap R1, sedangkan penambahan lebih lanjut (R3-R5) hanya menaikkan maksimum 12,4\%. R5 mempunyai S"MH tertinggi dan memberi peningkatan 92,1\% terhadap R1. Perbedaan torsi (S'MH -S'ML) menggambarkan modulus gesek dinamik yang secara tidak langsung terkait dengan kerapatan ikatan silang total dari sebuah kompon (Nabil et al., 2013; Indra et al., 2013). Sistem biner MBTS/ZDEC memberikan kerapatan ikatan silang lebih tinggi daripada akselerator tunggal MBTS. Pada rasio 1,2/0,4 phr (R5) kerapatan ikatan silangnya meningkat $96,2 \%$ dibanding rasio 1,6/0,0 (R1). Peningkatan tersebut merupakan kontribusi dari aktivitas sinergi kombinasi MBTS/ZDEC sesuai penjelasan diatas.

Faktor damping atau loss tangent $(\tan \delta)$ merupakan rasio elemen viskos dengan elastis. Tan $\delta(M L)$ merupakan loss tangent pada kompon, sedangkan $\tan \delta(\mathrm{MH})$ pada vulkanisat. Tan $\delta(\mathrm{ML})$ pada sistem akselerator biner (R2-R5) lebih rendah $28,9 \%$ daripada akselerator tunggal (R1). Hal tersebut menunjukkan dominasi elemen elastis sebagai akibat terbentuknya ikatan silang parsial (Gambar 3). Kompon dengan elastisitas besar berefek negatif pada proses karena sifat alirnya menurun. Penambahan ZDEC lebih lanjut menurunkan tan $\delta(\mathrm{ML})$ pada kisaran nilai yang sama. Tan $\delta(\mathrm{MH})$ vulkanisat dengan akselerator biner lebih besar daripada R2R5, dan penambahan ZDEC lebih lanjut menurunkan $\tan \delta(\mathrm{MH})$. Tan $\delta$ secara langsung berkorelasi dengan ikatan silangnya. Semakin kecil tan $\delta(\mathrm{MH})$ mengindikasikan ikatan silang yang semakin banyak (Nabil et al., 2013a). Tan $\delta(\mathrm{MH})$ semakin kecil menunjukkan dominasi elemen elastis yang semakin besar. Hal ini benar karena terbentuknya ikatan silang otomatis akan menaikkan elastisitas. Tan $\delta$ merupakan rasio energi yang hilang (energy lost) dan energi yang disimpan (energy stored) selama deformasi siklis.

\section{Karakteristik Curing}

Tabel 5 menunjukkan waktu scorch $\left(\mathrm{ts}_{2}\right)$, waktu optimum vulkanisasi $\left(\mathrm{t}_{90}\right)$ dan cure rate
Tabel 5. Karakteristik curing campuran NR/ EPDM

\begin{tabular}{cccc}
\hline Kode (rasio) & $\mathrm{ts}_{2}, \mathrm{~s}$ & $\mathrm{t}_{90}, \mathrm{~s}$ & $\mathrm{CRI}^{\mathrm{s}} \mathrm{s}^{-1}$ \\
\hline R1 $(1,6 / 0,0)$ & 84 & 495 & 0,243 \\
R2 $(1,5 / 0,1)$ & 76 & 299 & 0,448 \\
R3 $(1,4 / 0,2)$ & 72 & 235 & 0,613 \\
R4 $(1,3 / 0,3)$ & 60 & 204 & 0,694 \\
R5 $(1,2 / 0,4)$ & 51 & 198 & 0,680 \\
\hline
\end{tabular}

index (CRI). Sistem akselerator tunggal memberikan $\mathrm{ts}_{2}$ lebih tinggi daripada sistem biner. Penambahan ZDEC 0,1 phr menurunkan ts sebesar $9 \%$, sedangkan penambahannya lebih lanjut menurunkan maksimal 39,3\% pada R5.

Penurunan ts, disebabkan pada pemanasan awal kompon EPDM telah banyak terbentuk zat aktif sulfurating (Gambar (2) atau (3)). Semakin kecil ts ${ }_{2}$ menunjukkan semakin banyak zat aktif sulfurating yang terbentuk. Sistem biner MBTS/ ZDEC mempunyai ts ${ }_{2}$ lebih tinggi daripada akselerator tunggal MBTS karena efek aktivitas sinergis dari pasangan MBTS/ZDEC yang menghasilkan zat aktif sulfurating lebih banyak. $\mathrm{ts}_{2}$ juga merupakan pengukuran vulkanisasi dini pada matriks karet dan merupakan indikator keselamatan olah (scorch safety). Keselamatan olah merupakan waktu dimana kompon dapat dipertahankan pada suhu tinggi dan masih bersifat plastis. Waktu scorch menandai titik dimana material plastis mulai dikonversi secara kimiawi menjadi jaringan elastis (Manoj et al., 2011). Waktu scorch sangat penting karena menggambarkan jumlah waktu (heat history) dimana kompon dapat dipaparkan pada panas selama operasi pembentukan dan pencetakan. Semakin tinggi $\mathrm{ts}_{2}$ maka keamanan olah akan meningkat (Manoj et al., 2011). Oleh karena itu sistem biner memberikan keselamatan olah lebih rendah daripada sistem tunggal.

Waktu optimum curing $\left(\mathrm{t}_{90}\right)$ menurun dari R1 hingga R5 dan sistem akselerator biner memberikan $t_{90}$ lebih rendah daripada akselerator tunggal (Tabel 4). Penambahan ZDEC 0,1 phr (R2) menurunkan $\mathrm{t}_{90} 39,5 \%$ dibanding $\mathrm{R} 1$ dan penurunan terbesar diberikan oleh R5 mencapai $60 \%$. Penurunan $t_{90}$ terkait dengan pembentukan zat aktif sulfurating pada pemanasan awal kompon EPDM, sehingga 


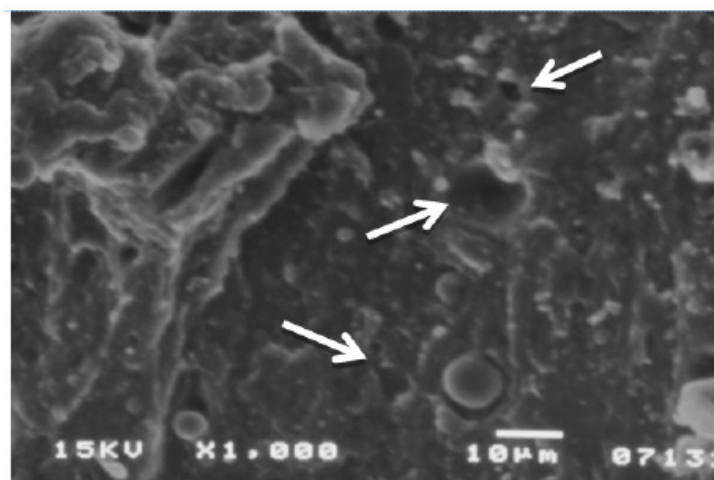

(a)

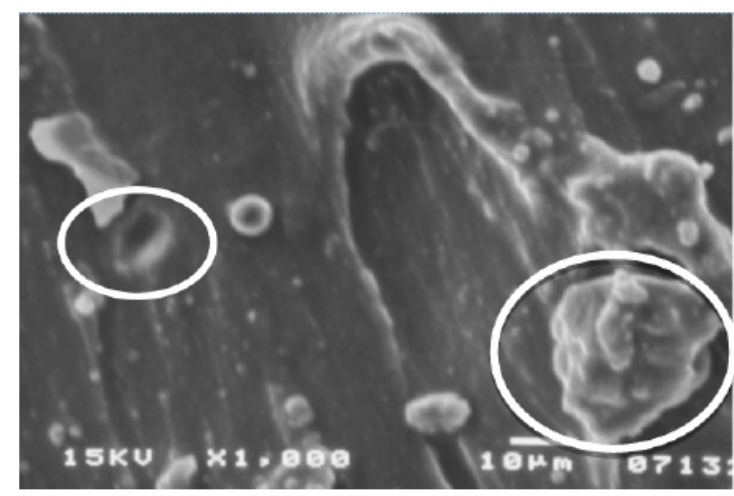

(b)

Gambar 6. Foto SEM, (a) R1 (rasio 1,6/0,0); (b) R5 (rasio 1,2/0,4)

waktu yang dibutuhkan hanya sedikit untuk bereaksi dengan hidrogen alilik (allylic) pada molekul NR sesuai dengan reaksi pada Gambar (5) (Nabil, et al., 2013). Semakin banyak zat aktif sulfurating yang terbentuk maka waktu yang dibutuhkan pun semakin sedikit sehingga $\mathrm{t}_{90}$ akan semakin kecil. Hal tersebut didukung oleh indeks kecepatan reaksi (CRI) yang semakin besar dari R1 hingga R5. Menurut Al Minath et al. (2011), semakin besar CRI maka semakin cepat reaksi vulkanisasi berlangsung.

\section{Sifat Morfologi}

Morfologi campuran NR/EPDM pada rasio MBTS/ZDEC 1,6/0,0 dan 1,2/0,4 digambarkan pada Gambar 6. Daerah berwarna gelap pada foto SEM menggambarkan fase dengan densitas lebih tinggi (NR), sedangkan daerah yang berwarna lebih cerah merepresentasikan fasa dengan densitas lebih rendah (EPDM) (Alipour et al., 2011). Morfologi R1 (Gambar 6(a)) menunjukkan permukaan yang kasar dengan beberapa lubang (void) kecil (anak panah putih). R5 menunjukkan morfologi yang lebih halus daripada R1 (Gambar 6(b)), tetapi ditemukan gumpalan cukup besar berukuran $\pm 20 \mu \mathrm{m}$, juga ditemukan adanya lubang kecil (lingkaran putih).

\section{Kekerasan dan Ketahanan Pegas Pantul (Rebound Resilience)}

Kekerasan dan ketahanan pegas pantul (resilience) merupakan sifat fisis dan mekanik yang penting dan erat kaitannya dengan struktur mikro rantai vulkanisat, seperti berat molekul dan kerapatan ikatan silang (Sun et al., 2012).
Gambar 7 menunjukkan sifat pegas pantul dan kekerasan vulkanisat R1 hingga R5.

Kekerasan meningkat dari R1 hingga R2 dengan nilai berkisar 54-62 Shore A. Peningkatan tersebut seiring dengan meningkatnya kerapatan ikatan silang seperti pada Tabel 3. Hasil yang sama dilaporkan oleh Dijkhuis et al.(2009). Indra, et al. (2013) menyatakan bahwa kekerasan bergantung pada derajat ikatan silang dan kenaikannya akan meningkatkan kekerasan. Sistem akselerator biner memberikan kekerasan lebih tinggi daripada akselerator tunggal. Hal tersebut disebabkan adanya aktivitas yang sinergi antara pasangan MBTS/ZDEC dimana dihasilkan kerapatan ikatan silang yang lebih tinggi. Kenaikan kekerasan menurunkan sifat pegas pantul seperti ditunjukkan Gambar 4. Sifat pegas pantul (rebound resilience) merupakan rasio energi yang dilepaskan oleh recovery dari deformasi terhadap energi yang dibutuhkan untuk menghasilkan deformasi (Indra et al., 2013; Nabil et al., 2013a). Sifat pegas pantul

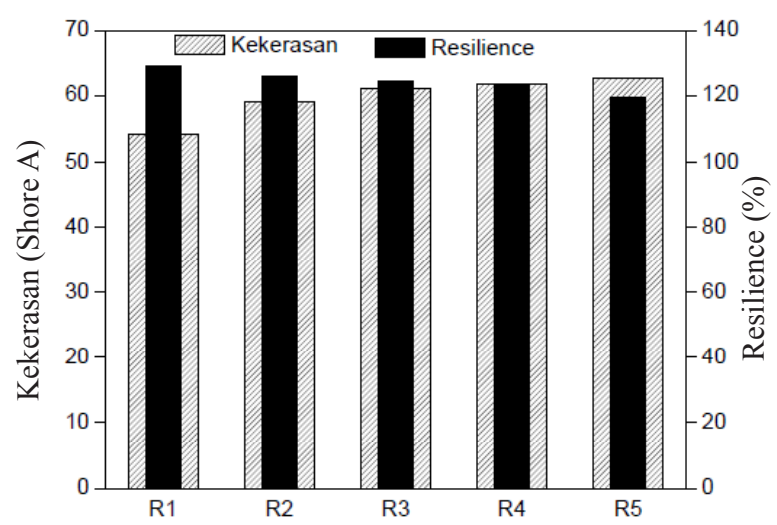

Gambar 7. Kekerasan dan resiliensi campuran NR/EPDM 
sebanding dengan derajat elastisitas (Ahmed et al., 2012). Secara umum kekerasan berkaitan dengan sifat pegas pantul dimana bahan yang sangat kaku (stiff) menunjukkan sifat pegas pantul yang rendah (Moonchai and Moonchai, 2013). Pada kerapatan ikatan silang yang tinggi massa molar rata-rata rantai karet diantara dua titik ikatan silang yang berurutan menurun dan mobilitas segmen rantai pun berkurang serta membatasi orientasi jaringan rantai. Karet menjadi lebih kaku dan fleksibilitas rantai molekul berkurang, akibatnya sifat pegas pantulnya menurun. Sifat pegas pantul yang menurun merupakan indikator berkurangnya elastisitas.

\section{KESIMPULAN}

Sistem akselerator biner MBTS/ZDEC menunjukkan sinergi aktivitas pada pencampuran reaktif NR/EPDM ditunjukkan dari kerapatan ikatan silang yang lebih tinggi daripada sistem akselerator tunggal MBTS. Penurunan $\mathrm{ts}_{2}$ dan $\mathrm{t}_{90}$, serta kenaikan CRI yang diberikan sistem biner menunjukkan distribusi ikatan silang yang lebih merata pada kedua fasa karet. Sistem biner memberikan kemampuan proses lebih rendah karena viskositas komponnya tinggi. Morfologi campuran NR/EPDM yang dihasilkan lebih homogen. Akselerator biner memberikan kekerasan lebih tinggi daripada akselerator tunggal, dan kekerasan meningkat dengan meningkatnya ZDEC dalam rasio MBTS/ZDEC. Kenaikan kekerasan diikuti dengan penurunan sifat pegas pantul. Kenaikan ZDEC dalam rasio MBTS/ZDEC menurunkan sifat pegas pantul.

\section{UCAPAN TERIMA KASIH}

Proyek penelitian ini dilaksanakan oleh tim kelompok kerja 1866.001.003.033 dan didanai oleh DIPA Balai Besar Kulit, Karet dan Plastik tahun anggaran 2013.

\section{DAFTAR PUSTAKA}

Ahmed, K., Nizami, S. S., Raza, N. Z. and Mahmood, K., 2012. Mechanical swelling, and thermal aging properties of marble sludge-natural rubber composites, International Journal of Industrial Chemistry, 3(21): 3-12.

Al Minnath, M., Unnikrishnan, G. and
Purushothaman, E., 2011. Transport studies of thermoplastic polyurethane/ natural rubber (TPU/NR) blends, Journal of Membrane Science, 379: 361-369.

Alam, M. N., Mandal, S. K., and Debnath, S. C., 2012. Effect of zinc dithiocarbamates and thiazole-based accelerators on the vulcanization of natural rubber, Rubber Chemistry and Technology, 85(1): 120131.

Alam, M. N., Mandal, S. K., Roy, K., and Debnath, S. C., 2014. Synergism of novel thiuram disulfide and dibenzothiazyl disulfide in the vulcanization of natural rubber: curing, mechanical and aging resistance properties, International Journal of Industrial Chemistry, 5(8): 120-131.

Alipour, A., Naderi, G., Bakhshandeh, G. R., Vali, H., and Shokoohi, S., 2011. Elastomer nanocomposites based on NE/ EPDM/organoclay: morphology and properties, International Polymer Processing, XXVI(1): 48-55.

Arayapranee, W. and Rempel, G. L., 2007. Properties of NR/EPDM blends with or without methyl methacrylate-butadienestyrene (MBS) as a compatibilizer, International Journal of Material and Structural Realibility, 5(1): 1-12.

Bhowmick, A., K. and Mangaraj, D., in Bhowmick A. K. et al. (eds), 1994. Vulcanization and curing techniques, in rubber products manufacturing technology, Marcel Dekker, New York.

Ghosh, P., Katare, S., Patkar, P., Caruthers, J. M., Venkatasubramanian, V., and Walker, K. A., 2003. Sulfur vulcanization of natural rubber for benzothiazole accelerated formulations: from reaction mechanism to a rational kinetic model, Rubber Chemisty and Technology, 76(3): 592-693.

Debnath, S. C. and Basu, D. K., 1994. Studies on cure synergism. I. Effect of safe zinc dithiocarbamate on NR vulcanization accelerated by thiazole-based accelerator, Journal of Applied Polymer Science, 52 (5): 597-603

Dijkhuis, K. A. J., Noordermeer, J. W. M., and Dierkes, W. K., 2009. The relationship between crosslink system, network 
structureand material properties of carbon black reinforced EPDM, European Polymer Journal, 45: 3302-3312.

Indra, S., Ismail, H., and Azura, A.R., 2013. Alkaolamide as an accelerator, fillerdispersant and a plasticizer in silica-filled natural rubber compound, Polymer Testing, 32(8): 1313-1321

Konar, B. B. and Saha, M., 2012. Influence of polymer coated $\mathrm{CaCO}_{3}$ on vulcanization kinetic of natural rubber/sulfur/ $\mathrm{N}$ oxydiethyl benzthiazyl sulfenamide (BSM) system, Journal of Macromolecul Science Part A: Pure Applied Chemistry, 49: 214226.

Manoj, K. C., Kumari, P., and Unnikrishnan, G., 2011. Cure characteristic, swelling behaviors, and mechanical properties of carbon black filler reinforced EPDM/NBR blend system, Journal of Applied Polymer Science, 120: 2654-2662.

Marković, G., Marinović-Cincović, M., Jovanović, V., Samaržija-Jovanović, S., and Budinski-Simendić, 2013. NR/CSM/ biogenic silica rubber blend composites, Composites B., 55: 368-373.

Moonchai, S. and Moonchai, D., 2013. Modelling and optimization of rebound resilience and hardness of defatted rice bran/calcium carbonate-filled NR vulcanisates, Polymer Testing, 32: 1472-1478.
Nabil, H., Ismail, H., and Azura, A. R., 2013. Effect of virgin ethylene-propylene-dienemonomer and its preheating time on the properties of natural rubber/recycled ethylene-propylene-diene-monomer blends, Material and Design, 50: 27-37

Nabil, H., Ismail, H. and Azura, A. R, 2013a. Compounding, mechanical and morphological properties of carbon-blackfiller natural rubber/recycled ethylenepropylene-diene-monomer blends, Polymer Testing, 32: 385-393

Sahakaro, K., Pongpaibon, C., and Nakason, C., 2009. Improved mechanical properties of NR/EPDM blends by controlling the migration of curative and filler via reactive processing technique, Journal of Applied PolymerScience, 111: 2035-2043.

Sae-oui, P., Sirinsinha, C., Thepsuwan, U., and Thaptong, P., 2007. Influence of accelerator type on properties of NR/EPDM blends, Polymer Testing, 26: 1062-1067.

Sun, J. T., Wang, W., Zhang, P., and Zhao, S. G., 2012. Effect of the synergy of hardness and resilience on the akron abrasion properties of SBR vulcanizates, Journal of Macromolecular Science Part B: Physic, 51: 1658-1667. 